\title{
ILUMILUTAS: tecnopolíticas da iluminação cênica, pedagogia crítica da luz e visualidades de corpos não-hegemônicos
}

\section{LIGHTFIGHTS: technopolitics of scenic lighting, critical pedagogy of light and visualities of non-hegemonic bodies}

Dodi Tavares Borges Leal ${ }^{1}$ 


\section{Resumo}

O texto sintetiza o primeiro ano de trabalho do ILUMILUTAS, projeto de pesquisa e extensão ligado ao curso de graduação em Artes do Corpo em Cena da Universidade Federal do Sul da Bahia, no Campus Sosígenes Costa. Fundado em 2018, o grupo tem como marca o cruzamento dos estudos da iluminação cênica com os processos sociais, desempenhando ações de investigação teórica e de suporte artístico laboratorial das matizes de luz e gênero, luz e sexualidade, luz e classe social, luz e processos étnico-raciais, etc. Sendo o primeiro projeto pedagógico de iluminação cênica no país dedicado exclusivamente aos processos sociais, O ILUMILUTAS destaca-se por assumir a pesquisa das visualidades da cena a partir de corporalidades não-hegemônicas, instaurando no campo da luz uma episteme tecnopolítica e uma pedagogia sócio-crítica.

Palavras-chaves: Pedagogia crítica da iluminação; luz e lutas sociais; corporalidades não-hegemônicas; visualidades da cena

\section{Abstract}

The text summarizes the first year of work of LIGHTFIGHTS, a research and extension project linked to the undergraduate degree in Performing Body Arts at the Federal University of Southern Bahia, at Sosígenes Costa Campus. Founded in 2018, the group has as its mark the intersection of studies of scenic lighting with social processes, performing actions of theoretical investigation and artistic laboratory support of the hues of light and gender, light and sexuality, light and social class, light and racial-ethnic processes, etc. Being the first pedagogical project of scenic lighting in the country dedicated exclusively to social processes, ILUMILUTAS stands out for taking on the research of the visualities of the scene from non-hegemonic corporealities, establishing in the field of light a technopolitical episteme and a socio-critical pedagogy.

Keywords: Critical pedagogy of lighting; light and social struggles; non-hegemonic corporealities; visualities of the scene 
O grupo de estudos ILUMILUTAS consiste em promover um espaço permanente de experimentação artística e reflexão crítica sobre processos estéticos, procedimentos e equipamentos de iluminação cênica. Almeja-se um contexto dialógico e de troca de saberes e práticas nas quais se investiga interfaces da luz cênica com lutas sociais contra a opressão.

Coordenado pela Profa. Dra. Dodi Tavares Borges Leal ${ }^{2}$, trata-se de um projeto de pesquisa e de extensão universitária vinculado ao curso de segundo ciclo (profissionalizante) Bacharelado em Artes do Corpo em Cena, oferecido no Centro de Formação em Artes da Universidade Federal do Sul da Bahia (CFA-UFSB). O grupo de estudos ILUMILUTAS ${ }^{3}$ oferece subsídios técnicos, teóricos e artísticos para os vários momentos de desenvolvimento da trajetória acadêmica de estudantes do curso Artes do Corpo em Cena (e outros da UFSB) nas atividades ligadas à dança, performance e teatro.

Desde sua criação e início de atividades, em novembro de 2018, o grupo de estudos mantém encontros regulares abertos à comunidade acadêmica da UFSB, bem como ao público externo. Como projeto de pesquisa, o ILUMILUTAS articula atividades epistemológicas em torno da criação cênica a partir da linguagem da luz, dando subsídios a investigações de iniciação científica e de conclusão de curso de graduação.

Porto Seguro, município do Sul do estado da Bahia, e territórios adjacentes, compreendem uma extensa área na qual estão situados diversos núcleos históricos, comunidades indígenas, movimentos culturais periféricos urbanos, coletivos de arte, centros de cultura, escolas de arte, etc. compondo assim uma significativa e heterogênea rede de produção cultural e artística. No que tange às produções em Dança, Teatro e Performance, no entanto, a região está em um estágio de formação e desenvolvimento no qual a Universidade Federal do Sul da Bahia, fundada em 2013 e inaugurada em 2014, e outras instituições culturais que aqui atuam têm um papel fundamental de suporte e estruturação de canais para a produção artística local.

Temos que, a precariedade de equipamentos de iluminação e inexistente formação profissional em tecnologias da cena na região são não somente um obstáculo à expressão artística das comunidades, mas igualmente um elemento que reduz as possibilidades de experimentação crítica e estética sobre os processos sociais vividos na região. Um aspecto central do ILUMILUTAS recai, portanto, na capacidade de conectar por atividades práticas e teóricas os/as agentes culturais e artísticos da região com estudantes da UFSB e assim criar subsídios formativos em iluminação cênica e investigações sociais potencializadas pela luz.

\footnotetext{
2 Vinculada à vaga "Artes Cênicas / lluminação e novas tecnologias aplicadas ao corpo e à cena / Práticas Artísticas / Campo das Artes / Criação Cênica", aprovada no concurso público docente Edital 11/2018 da UFSB.

${ }^{3}$ Atualmente o ILUMILUTAS conta com a participação da Profa. Dodi Leal (coordenadora do projeto, e professora do curso Artes do Corpo em Cena - CFA/UFSB e da Licenciatura Interdisciplinar em Artes - IHAC/CSC/UFSB), Marcos Fernandes (estudante do Bacharelado em História CFCHS/UFSB; licenciado em Artes Cênicas pela UFBA), Breno Terra (estudante do Bacharelado Interdisciplinar em Artes IHAC/CSC/UFSB), Khalil Piloto (estudante do Mestrado Profissional em Ensino e Relações Étnico-Raciais IHAC/CSC/UFSB), ManaCaiene (estudante do Bacharelado em Artes do Corpo em Cena CFA/UFSB), Vinícius Santos (estudante do Bacharelado em Artes do Corpo em Cena CFA/UFSB), Caz Ângela (estudante do Bacharelado Interdisciplinar em Artes IHAC/CSC/UFSB) e Jean Isaac (estudante do Bacharelado Interdisciplinar em Artes IHAC/CSC/UFSB), além da Profa. Aline Nunes (professora do curso Artes do Corpo em Cena - CFA/UFSB e da Licenciatura Interdisciplinar em Artes - IHAC/CSC/UFSB).
} 
Este texto aborda o primeiro ano de trabalho do grupo, dando destaque às atividades pedagógicas em torno da iluminação em seus traços sociais do corpo, especificamente: luz e gênero; luz e sexualidade; luz e classe social; luz e processos étnico-raciais. Almejamos destacar no artigo como os processos sociais do corpo podem ser atribuição nevrálgica de profissionais que atuam como designers de luz (Leal, 2018b). "Não criamos apenas beleza e conforto, como criamos também consciência estética, de harmonia, de respeito humano, ecológica em seu sentido mais abrangente", comenta Perez (2012, p.26) sobre atividades de designers de luz.

Pretende-se perceber por meio das experiências do projeto de pesquisa e extensão ILUMILUTAS/CFA/UFSB, aqui relatadas, quais os aportes da perspectiva tecnopolítica da luz em tensão com as corporalidades, consubstanciando vetores de uma pedagogia sócio-crítica da iluminação cênica.

\section{Pedagogia visual da cena: novos corpos, novas luzes?}

Pretendemos aqui discutir uma abordagem pedagógica específica da visualidade da cena, sobretudo no que se refere ao campo da iluminação. A primeira pergunta que podemos formular é: quais os parâmetros do ensino da iluminação cênica a partir de processos corporais? A partir da proposta de que a corporalidade constitui-se como fundamento cênico em sua midialidade (Leal, 2018a), buscamos aqui refletir sobre os aspectos sociais do corpo como vetores de trabalho da pedagogia da luz.

Neste sentido, observamos que tradicionalmente o ensino da iluminação cênica se desenvolveu nas escolas brasileiras com uma abordagem generalista de corpo, ou seja, sem levar em discussão o desenho da pedagogia da luz a partir dos processos étnico-raciais, de gênero, de sexualidade, de peso, de classe social, etc. Em uma assunção geral de corpo sem matizar os condicionamentos sociais, percebemos que o ensino da luz incorre na corroboração dos parâmetros hegemônicos que marcam as corporalidades: a branquitude, a cisgeneridade, a magreza, a monossexualidade, a perspectiva elitizada, etc (Leal, 2019b). Neste sentido, perguntamos, como pensar a luz a partir de gênero, a partir da raça/etnia, a partir do peso, a partir da classe social, a partir da sexualidade?

Mais do que responder a última pergunta, nos parece que esta é uma tarefa urgente e ampla que envolve a elaboração de muitas outras perguntas subjacentes, as quais podem ser feitas (e estão sendo cada vez mais feitas) em múltiplos pontos de experiência. Então, mais do que arranjar uma nova forma de iluminar corpos não hegemônicos, o que apontamos como desafio para a área versa sobre: $O$ que o corpo negro tem a ensinar para a iluminação cênica? O que o corpo transgênero tem a ensinar sobre o fazer e o pensar da luz? Quais saberes de corporalidade o corpo gordo, o corpo velho e o corpo com mobilidade reduzida podem aportar no sentido de reconfigurar a lógica da área da iluminação cênica? Estas e outras perguntas não visam esgotar a discussão dos processos sociais da iluminação cênica: visam abrir o campo de estudo. 
De 28 de janeiro a 1 de fevereiro de 2019 foi oferecido o I Workshop de Introdução à Iluminação Cênica pelo ILUMILUTAS no Centro de Cultura de Porto Seguro. A condução foi realizada pela Profa. Dodi Leal, Marcos Fernandes e Breno Terra. Com a carga de $20 \mathrm{~h}$ e a presença de 40 participantes, a atividade efetivamente mobilizou artistas, educadoras/es e estudantes da região em torno das práticas da iluminação como uma linguagem que cruza o fazer criativo em várias esferas.

Planejado pelo grupo durante os meses de novembro/18, dezembro/18 e janeiro/19, o workshop associou-se a estudos conjuntos de textos sobre iluminação cênica, estudos étnico-raciais e estudos de gênero. Neste primeiro momento, as referências compartilhadas, lidas e discutidas conjuntamente no grupo foram os textos: A visão de um projeto aberto (Guilherme Bonfanti, 2018), As vozes que escutamos no caminho (Jaqueline Gomes de Jesus, 2019) e A Humanidade que Pensamos Ser (Ailton Krenak, 2019). O primeiro texto, escrito pelo designer de luz do Teatro da Vertigem, trata de sua trajetória no grupo e suas considerações sobre a pesquisa de criação em relação com o espaço. Já os dois outros textos compõem o catálogo da Mostra Internacional de Teatro de São Paulo (MITsp), 6a edição (2019), na qual a coordenadora do ILUMILUTAS atuou como crítica teatral, tendo escrito quatro textos ${ }^{4}$ nos quais indica os aspectos de iluminação cênica em jogo.

O preparo do material teórico e pedagógico do curso somou-se a uma das inquietações do grupo: o fato de a universidade não dispor de equipamentos de iluminação cênica até então. Neste sentido, a parceria com o Centro de Cultura de Porto Seguro trouxe a oportunidade de viabilizar o estudo de refletores e das possibilidades de criação de luz em um espaço cênico que tende ao palco italiano. Ainda que tínhamos como vetor os estudos dos trabalhos do Teatro da Vertigem que leva em conta a ressignificação de espaços e a criação cênica em topografias não-convencionais, pensamos que seria importante neste momento aportar ferramentas e subsídios críticos ao cenário local considerando o palco disponível.

O sentido de arquitetura teatral e espaço cênico ampliaram-se para uma diversidade de proposições de relação palco/plateia no teatro contemporâneo, mas as formas tradicionais ainda são marcos para entendermos as configurações dos campos de visão e interação entre os corpos e olhares que participam de espetáculos cênicos seja na cena, seja na plateia. (Figueiredo, 2018, p.155).

\footnotetext{
4 Os textos são: 1) Ser ou não ser? Esta não deveria ser a questão. Mas é! (Crítica da peça A REPETIÇÃO. HISTÓRIA(S) DO TEATRO (I), TíTULO ORIGINAL: THE REPETITION. HISTOIRE(S) DU THÉÂTRE (I), DIREÇÃO: Milo Rau, Bélgica | 2018 | 1h40min | Classificação indicativa: 16 anos). Disponível em: https:/l mitsp.org/2019/ser-ou-nao-ser-esta-nao-deveria-ser-questao-mas-el, acesso em: 30/10/2019 às 16h50, Porto Seguro / BA, Brasil; 2) Luz à sombra do som (Crítica da peça ALTAMIRA 2042, DIREÇÃO: Gabriela Carneiro da Cunha, Brasil | 2019 | 1h30min | Classificação indicativa: 16 anos). Disponível em: https:// mitsp.org/2019/luz-sombra-do-som/, acesso em: 30/10/2019 às 16h52, Porto Seguro / BA, Brasil; 3) Mão na testa e trans pro frágil. (Crítica da peça MANIFESTO TRANSPOFÁGICO. CRIAÇÃO, DRAMATURGIA E INTERPRETAÇÃO: Renata Carvalho, DIREÇÃO: Luiz Fernando Marques, Brasil | 2019 | 50 min | Classificação indicativa: 18 anos). Disponível em: https://mitsp.org/2019/mao-na-testa-e-trans-pro-fragil-por-dodi-leal/,acesso em: 30/10/2019 às 16h54, Porto Seguro / BA, Brasil; e 4) Netuno é travestruz (Crítica da peça MDLSX, DIREÇÃO: Enrico Casagrande e Daniela Nicolò. INTERPRETAÇÃO: Silvia Calderoni, Itália | 2018 | 1h20min | Classificação indicativa: 16 anos). Disponível em: https://mitsp.org/2019/netuno-travestruz/, acesso em: 30/10/2019 às 16h56, Porto Seguro / BA, Brasil.
} 


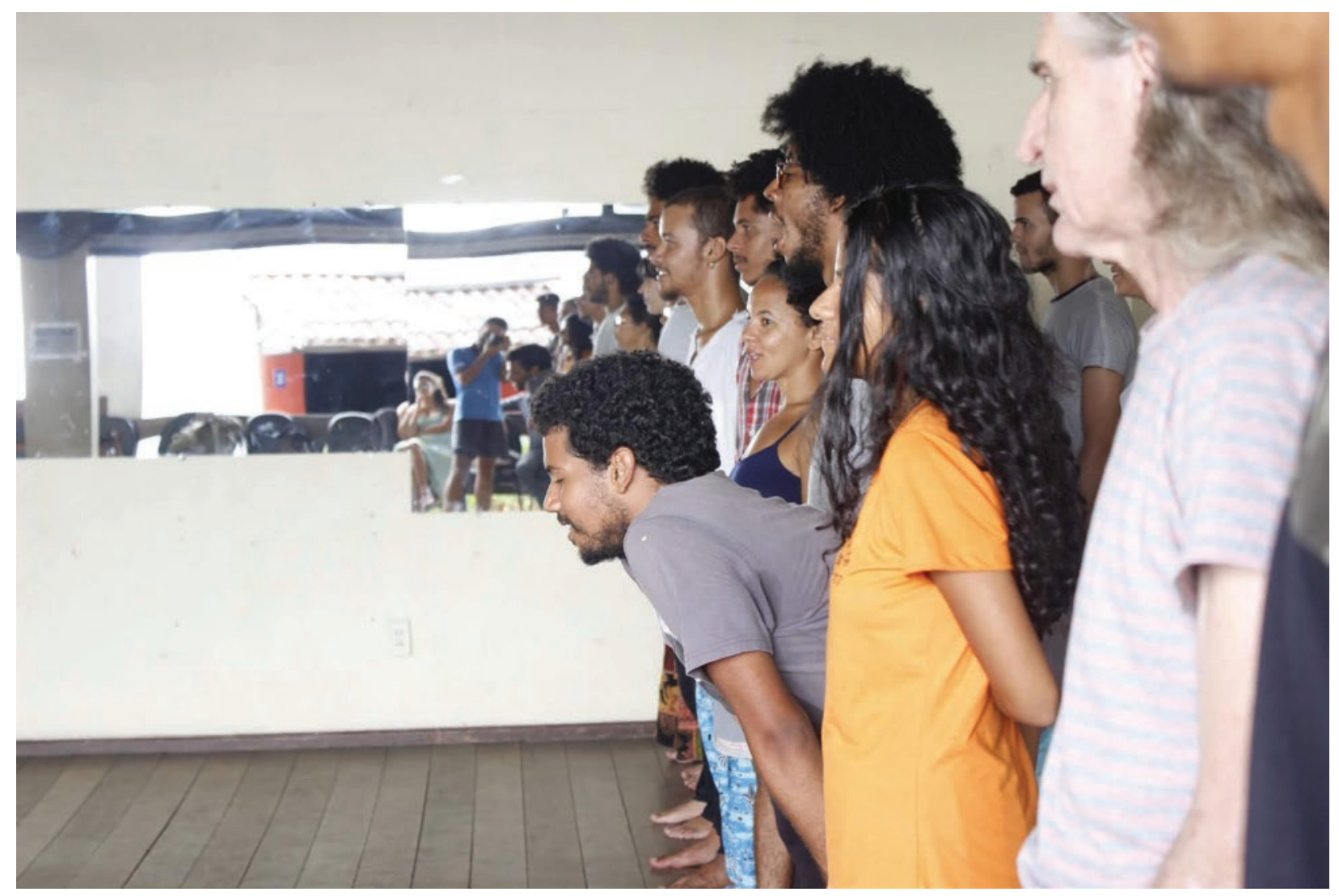

Registro fotográfico do I Workshop de Introdução à lluminação Cênica

Fonte: Breno Terra

Por se tratar de uma abordagem de ensino da iluminação a partir das corporalidades, tivemos como metodologia do primeiro dia de encontro jogos teatrais que despertaram: a desmecanização do cotidiano, a atenção ao espaço, dinâmicas de fluxo de movimentos, a criação de gestualidades a partir da espontaneidade e a atuação/prontidão cognitiva em relação ao grupo. Sendo o Sul da Bahia predominantemente composto por pessoas negras e por ser a professora Dodi uma mulher trans, a busca por possibilidades expressivas do corpo a partir dos marcadores sociais de desigualdade apresentou-se de maneira fluída entre todas/os desde este primeiro dia. Nas aulas seguintes as discussões avançaram.

No segundo dia, a turma se dividiu em 7 grupos, os quais leram e discutiram excertos de capítulos do livro Função estética da luz (Camargo, 2000), a saber: 1) Luz e visibilidade; 2) Luz e criação; 3) Luz e realidade; 4) Luz e atmosfera; 5) Luz e expressão; 6) Luz e espaço; e 7) Luz e movimento. Em seguida, no grande grupo, tivemos a oportunidade de compartilhar as reflexões feitas em cada tópico e relacionar com os jogos feitos no dia anterior. 


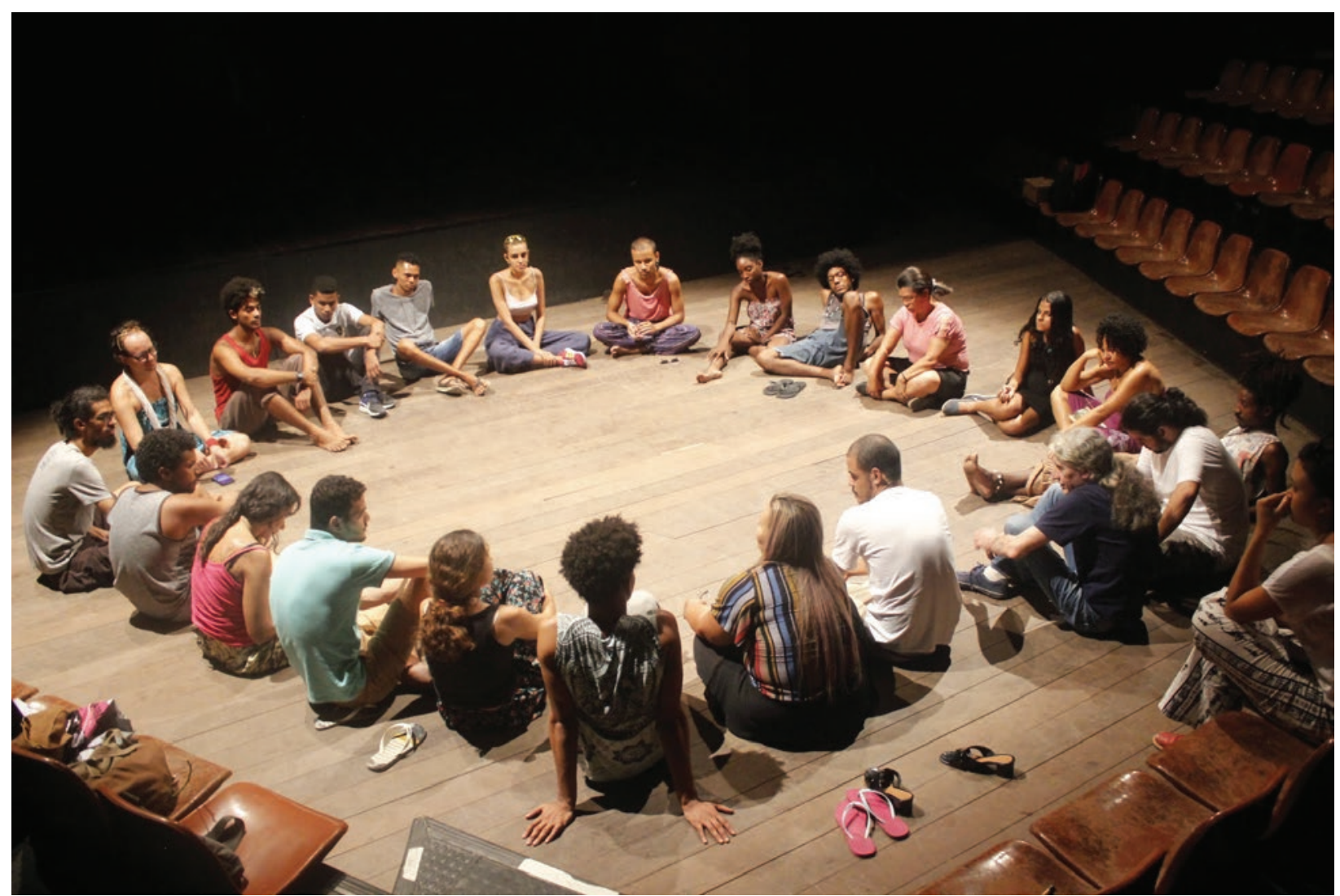

Registro fotográfico do I Workshop de Introdução à lluminação Cênica Fonte: Breno Terra

As seguintes questões apareceram: Como aprender a luz a partir do corpo? Como a cognição dos jogos pode preparar para a atenção cênica exigida na operação de luz? Quais os componentes sociais e políticos do corpo e como eles vetoriam a estética da iluminação cênica? Neste momento foi solicitado que a Profa. Dodi apresentasse sua pesquisa em torno das transgeneridades e as relações com a iluminação cênica. Destacou-se aí o conceito luzvesti: "a força lírica de expressão visual das desobediências de gênero a partir do potencial performativo da luz cênica". (Leal, 2018a, p.73).

No terceiro dia, Marcos Fernandes deu instruções sobre eletricidade, seguida da demonstração dos tipos de refletores cênicos disponíveis no Centro de Cultura de Porto Seguro. Cabe destacar que solicitamos o rider técnico da instituição com antecedência e que fizemos um acordo de que somente as pessoas que ministraram o workshop poderiam manipular os equipamentos e subir nas escadas do espaço, por uma precaução de segurança. Na sequência, a Profa. Dodi apresentou imagens do livro Haja Luz! Manual de Iluminação Cênica de Marcelo Santana (2016), no que se refere às funções da luz cênica, procurando destacar a leitura e a percepção do grupo, ativando a análise estética e social da luz. Alguns tópicos remeteram a relações com relação aos textos lidos e discutidos no dia anterior: visibilidade; velar/desvelar; tridimensionalidade; modelagem: textura; modelagem: cor, forma e volume; modelagem: cor; seletividade; e atmosfera. No terceiro momento deste mesmo dia trabalhamos com a formação de quatro grupos os quais teriam como desafio a criação de 
uma cena instalativa com o intuito de ser apresentada no último dia das aulas. No dia seguinte os grupos precisariam apresentar o mapa de luz de cada cena.

No quarto dia, Breno Terra fez a apresentação de uso de softwares para a elaboração de mapas de luz. As duas aplicações expostas foram: LABLUX (elaborada pelo Laboratório de Iluminação da UNICAMP) e Whitecat (software livre criado pelo projeto espanhol CITILAB). Como os grupos ainda não tinham familiaridade com estes dispositivos, os mapas de luz das cenas instalativas foram apresentados oralmente com o suporte de desenho em papel (projetado na tela). Os questionamentos sobre as relações sociais do corpo em relação às possibilidades da luz atravessaram todo o curso. Como criar um projeto de luz em aplicativo pensado a partir do corpo? E se o corpo se ausenta da cena, quais as possibilidades dramáticas de sua sugestividade social?

A presença de dois tipos luz: difusa e ativa, cria o claro/escuro, configurando imagens diversas para se olhar o corpo humano e cenografia, conforme a incidência da luz numa área focal (ativa) do espaço, capaz de gerar mais sombras; ou sob a ação da luz difusa espalhada uniformemente pela cena. Das interações entre estes dois tipos de iluminação se abrem inúmeras possibilidades de criação de imagens poéticas visuais e atmosferas dramáticas, por meio dos jogos dos movimentos de luzes e sombras sobre cenários e no corpo humano que interagem com eles no espaço cênico. (Figueiredo, 2018, p.158).

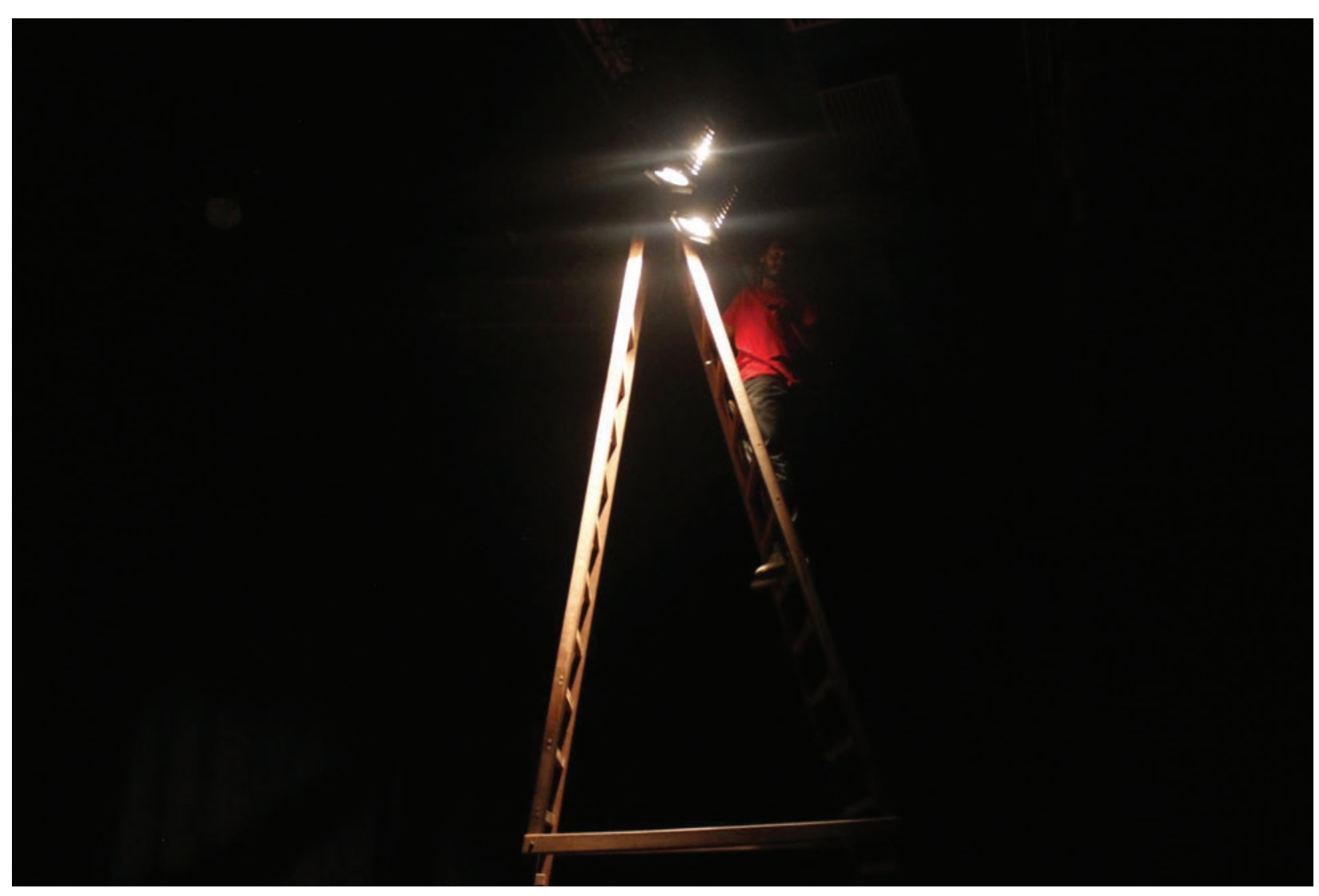

Registro fotográfico do I Workshop de Introdução à lluminação Cênica Fonte: Breno Terra 
Já no último dia, oportunizamos um tempo de montagem das cenas. Por decisão coletiva em função do tempo disponível, os grupos escolheram um dos projetos para a apresentação. Na ocasião, ainda antes da finalização do workshop, trabalhamos em esquema de revezamento na operação da mesa de luz em interface com a instalação no palco que tinha uma luz a pino. Curioso foi que uma escada de madeira utilizada para acesso às varas do palco tornou-se um objeto cênico, assim como peças de roupa, em destaque um vestido. A cena ganhou vida com variações de tema em trocas de pontos de luz, alterando entre a frontal e a contraluz. Também um texto de poesia de criação de um/a das/os participantes, e recitado pelo grupo, em vozes diferentes (e por fim em coro), trouxe a narrativa completa da experiência. $\mathrm{Na}$ ocasião destacamos o jogo de sombras criado com o vestido, a ausência do corpo como sugestão do próprio corpo em cena, a partir do traje e da voz.

Ao final do workshop além de tratarmos coletivamente da avaliação do percurso, passamos uma ficha para preenchimento no qual as/os participantes poderiam manifestar aspectos interessantes e insuficientes do trabalho. De acordo com as respostas obtidas, os destaques de maior impacto do workshop que acrescentaram aos conhecimentos prévios do grupo foram: jogos teatrais como percurso de vivência da iluminação cênica; discussão teórica e crítica sobre iluminação; correlação da iluminação cênica com os estudos de gênero e étnico-raciais; e criação de projeto de luz e exercício de instalação cênica. Como aspecto insuficiente do Workshop apontou-se unanimemente: a carga de 20h mostrou-se curta para os anseios das/os participantes e a potencialidade dos materiais dispostos no processo formativo.

\section{Arandelas: desmontagem cênica de iluminação e gênero}

O evento ARANDELAS consiste numa sessão pública de desmontagem onde artistas mulheres cis e trans são convidadas a apresentar seus trabalhos cênicos para, em seguida, demonstrarem seu processo de produção, com destaque aos dispositivos criativos de iluminação e de gênero, em diálogo com os elementos textuais, sonoros e espaciais da criação performativa.

De acordo com a Professora Ileana Diéguez Caballero (Universidad Autónoma Metropolitana - México), desmontagem cênica é um procedimento que busca tornar visíveis os dispositivos, os detonadores de uma ação, as paixões e razões de sua construção. "A desconstrução remete a uma prática filosófica e política aplicada a textos da linguística, literatura, arte, religião, filosofia, evidenciando os sistemas de poder que os habitam" (Caballero, 2014, p.7). Neste sentido, a principal pergunta que atravessa esta proposta é: como assistir uma obra artística e destacar dela os seus detonadores sócio-políticos de iluminação cênica? Associada a ela, interrogamos, como o gênero se insere na desmontagem cênica de iluminação de uma obra?

A primeira sessão do Arandelas aconteceu dia 1 de agosto de 2019 no Campus Sosígenes Costa da UFSB com duas atrações, mediadas pela Profa. Dodi Leal, sendo uma delas parte de um projeto contemplado por projeto de fomento cultural interno da UFSB. Em parceria com o componente Alteridade e Cinema nas Américas, ministrado pelo Prof. Bernard Belisário, tratou-se de apresentar as ações em diálogo direto com o contexto de ensino regular dos cursos de Bacharelado e Licenciatura 
Interdisciplinares do IHAC. Após as exibições, a mediadora provocou a realização junto ao público de dois excertos retirados das obras, com destaque a elementos de iluminação cênica de gênero, de sexualidade e de processos étnico-raciais. As duas apresentações foram as seguintes:

1) PERFORMANCE: Amamenta-se Zeus: leite de picadura; zangão não faz mel, mas também não mama. 1 h15 com Caz Ångela - Estudante do Bacharelado Interdisciplinar em Artes do IHAC/UFSB. Artista idealizadora do Pacote de Performances de Autocuidado e de Proteção (Lugar de Cultura - Edital Prosis 08/2019). SINOPSE: Amalteias, as más teias, as amas, as armas meladas, Melissas, ninfas que dão de comer, alimentam a divindade; mas de que "divino" se fala? É alimento a fala, o falo? Pensando nas que sempre foram negadas ao leite, mas que até aos deuses amamentaram esta performance intenc(s)iona inverter a luz sobre a mesa, as tetas, sobre a cama, sobre nossas corpas e no ato performático questionar o que é o leite, o que é o mel, o que se come, o que se goza, o que é prazer, o que é nutrição; o que é dar, dar sustento ao organismo, ao social, ao espírito? Através do contato direto com o público a performer dá e recebe os questionamentos que são sua fome e sua própria comida. Quem come? Quem alimenta? Quais corpos come? Quais nutre?

2) FILME: DEGENERADxS (2017/2018). 29min42s com Marina Mathey - Cantarina e bailatriz em visita artística no Centro de Formação em Artes UFSB (de 31/7 a 10/8) - projeto ENCRUZI-TRAVA ${ }^{5}$. Dirigiu o filme DEGENERADxS pelo Coletivo Transviadas Libertárias (Prêmio VAl audiovisual - Secretaria Municipal de Cultura de São Paulo). SINOPSE: Corte, espelho, relação, embate, ocupação, fricção. A partir dos registros do processo criativo e das performances realizadas pelx Coletivx Transviadas Libertárias em 2017 pelos bairros de Sampã, DEGENERADxS é a construção de uma metáfora político-performativa em formato de curta-metragem se propondo a friccionar as realidades e possibilidades de um corpo que foge às normas vigentes habitando os espaços públicos da cidade grande. São Paulo é o cenário social. A sala de ensaio um universo onírico, inconsciente, quase individual. Quanto pode um corpo fora da norma? O que o meu gênero, minhas manifestações e meus desejos sexuais dizem hoje em meio à 12,11 milhões de habitantes na maior capital do Brasil? E o que somos nós se não a performance de nossa visão de mundo, de nossa ética, de nossas verdades?

Tendo em perspectiva o dialogismo da iluminação cênica, não apenas no que se refere ao potencial de múltiplas significações de leitura, mas principalmente pelas inscrições subjetivas que provoca em sua efemeridade e em relação com a recepção, a sessão de Arandelas teve como desafio destacar o aspecto experiencial das atrações.

A luz cênica é uma experiência compartilhada. Algo que se manifesta em conjunto, mobilizando diversos discursos e impressões subjetivas ao mesmo tempo. É uma comunicação silenciosa, aberta, sensorial, indescritível. Um dialogismo entre diversas formas de ver, perceber e sentir. O resultado dessa experiência com luz não constitui um objeto único, estabelecido a priori com a convicção de atingir uma unanimidade, mas sim uma dispersão de subjetividades. (Camargo, 2018, p.219-220).

\footnotetext{
${ }^{5}$ A artista paulista Marina Mathey esteve em visita artística no CFA/UFSB de 31/7 a 11/8/19. Na ocasião ela atuou em diversas atividades acadêmicas de ensino e de extensão, com destaque ao show TRAVA realizado na Abayomi Casa de Cultura, no I Sarará Trans: um sarau do protagonismo da negritude trans, e ofereceu a oficina AArte da performance e a contrassexualidade da iluminação cênica juntamente com a Profa. Dodi Leal, relatada no tópico seguinte deste artigo.
} 
Após a vivência da performance e a exibição audiovisual, a desmontagem cênica operou em trazer dois excertos da fruição do público em destaque, tendo a iluminação cênica como suporte e gênero como tema. O conjunto total de espectadores/as que acompanhou as duas apresentações foi em torno de 100 pessoas entre estudantes, docentes e pessoas sem vínculo institucional com a UFSB. Os elementos escolhidos foram: a luz negre no caso da performance e a vela no caso da obra audiovisual. A mediação se deu em torno da experimentação junto à recepção dos elementos e possibilidades concretas destes materiais, levando em conta também suas redes de significação.

A luz negre é emitida a partir de uma lâmpada de luz ultravioleta, de onda longa (UV-A). Vendida com a indicação de gênero neutro em português (com designação final "e"), a marca adquirida foi rapidamente associada às transgeneridades. O fato de o conteúdo semântico da negritude destacar-se no nome deste dispositivo instaurou uma atenção adicional do público que procurou indícios étnico-raciais da operatividade de sua visualidade. Um dos comentários mais ressoados nesta ocasião foi quando alguém do público: "é curioso que a luz negre, apesar do nome, realça o branco". Ainda que tenha referindo-se explicitamente às vestes brancas, o grupo associou o ponto reflexivo à pele negra e em seguida partiu para a experimentação do efeito desta luz em relação a corpos negros.

$\mathrm{Na}$ etapa seguinte, realizamos uma experimentação com o uso de velas, a partir de alguns ensejos do produto fílmico que remetiam ao processo criativo utilizado no projeto de DEGENERADxS. Trata-se do Bukkake, modalidade de sexo grupal originada no Japão, onde o gozo coletivo incide em uma mulher no centro ${ }^{6}$. Realizamos a experiência da luz/fogo da vela enquanto produção de gozo/cera, o qual voluntários/ as experimentaram na pele. A prática, inspirada em um redimensionamento das condições cisnormativas de produção do prazer, abriram caminho para uma nova oficina do ILUMILUTAS que viria a desvendar uma nupérrima possibilidade da iluminação cênica, em seus múltiplos aparatos: a produção de prazer e as práticas disruptivas de modificar funcionalidades de seus elementos de luz, deslocando zonas erógenas a partir do calor e da fruição visual. Relata-se a oficina a seguir.

\section{A arte da performance e a contrassexualidade da iluminação cênica}

A oficina que teve o título desta seção, aconteceu no dia 3/8/2019, teve a duração de 6 horas e a participação de 6 pessoas e duas facilitadoras: Marina Mathey e Profa. Dodi Leal. A realização se deu em uma nova parceria entre o ILUMILUTAS / Centro de Formação de Artes da UFSB e o Centro de Cultura de Porto Seguro.

Diferentemente da primeira oficina, relatada anteriormente, nesta ocasião foi prescindível o acesso aos equipamentos de iluminação do prédio. Almejou-se com esta oficina exatamente a pesquisa de dispositivos de luz não-convencionais para a cena. Neste sentido, intuía-se que a pesquisa com elementos diferentes dos refletores poderia expandir a pesquisa aproximando o fazer pedagógico das buscas em

${ }^{6}$ Mais informações em: https://pt. wikipedia.org/wiki/Bukkake, Acesso em: 30/10/2019 às 18h06, Porto Seguro / BA, Brasil. 


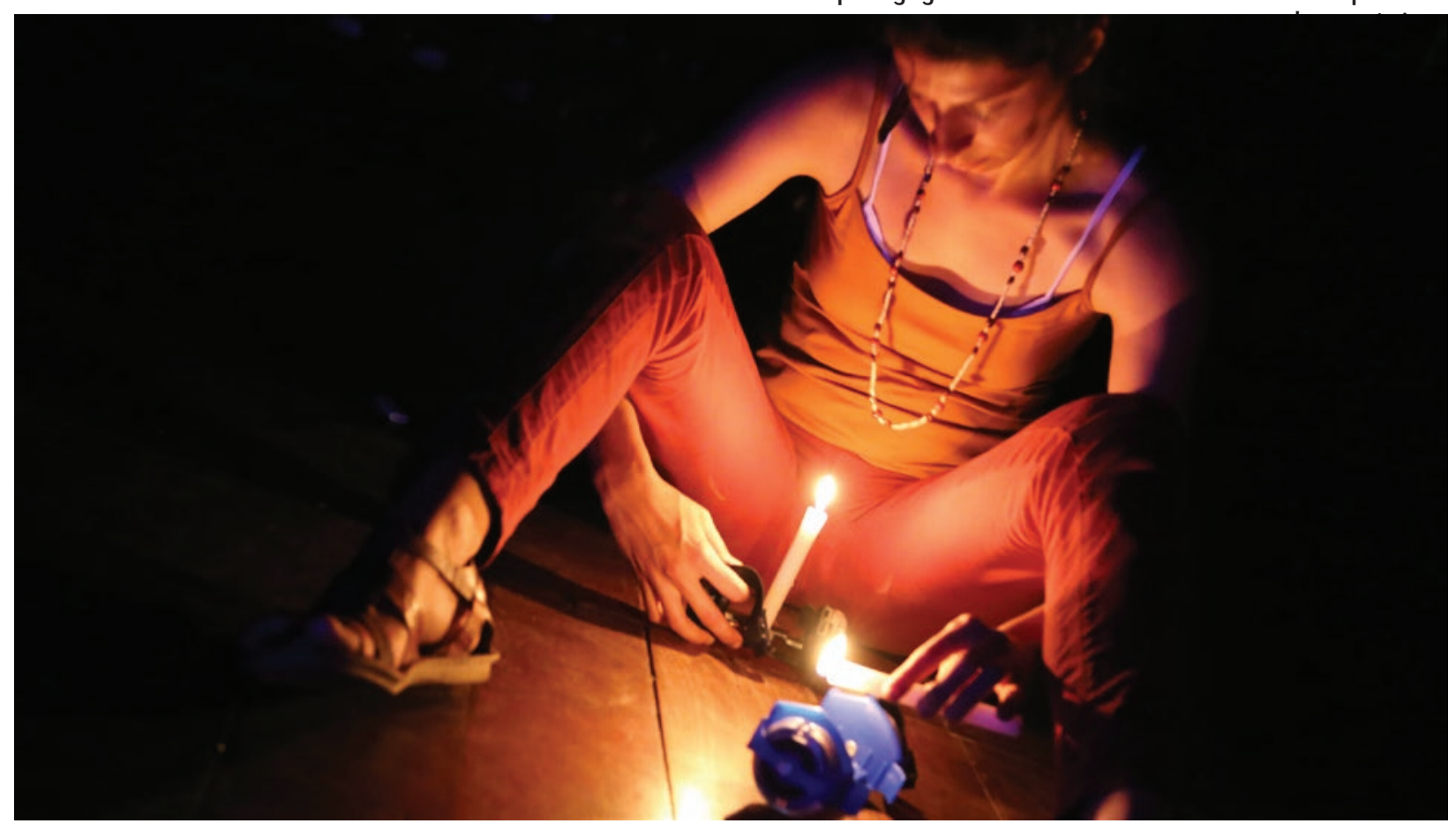

Registro fotográfico da Oficina: A Arte da Performance e a Contrassexualidade da lluminação Cênica Fonte: Marina Mathey

Caracterizando-se por uma estrutura narrativa e representacional, o teatro maneja códigos com a finalidade de realizar determinada inscrição simbólica do assunto, ao contrário da performance, que expressa fluxos de desejo e tem por função desconstruir o que o primeiro formatou. (Fernandes, 2013, p.123).

Tendo como desafio as variações semânticas do sexo investigadas a partir das variações semânticas da luz, nos pareceu que a arte da performance traria mais subsídios de risco e liminaridade do corpo (Leal, 2019b), condições para compreender e agir a corporalidade no contexto pedagógico desta proposta. Tínhamos como referência fundamental da oficina o livro Manifesto contrassexual de Paul Preciado (2014) e ambicionamos, então, desenvolver um percurso prático corporal inspiradas nesta produção teórica, alçando-nos nela a partir da experiência pedagógica com a iluminação cênica. Algumas questões atravessaram o planejamento da oficina, uma das principais foram: de que maneira a luz cênica pode ser uma fonte de prazer sexual do corpo? 


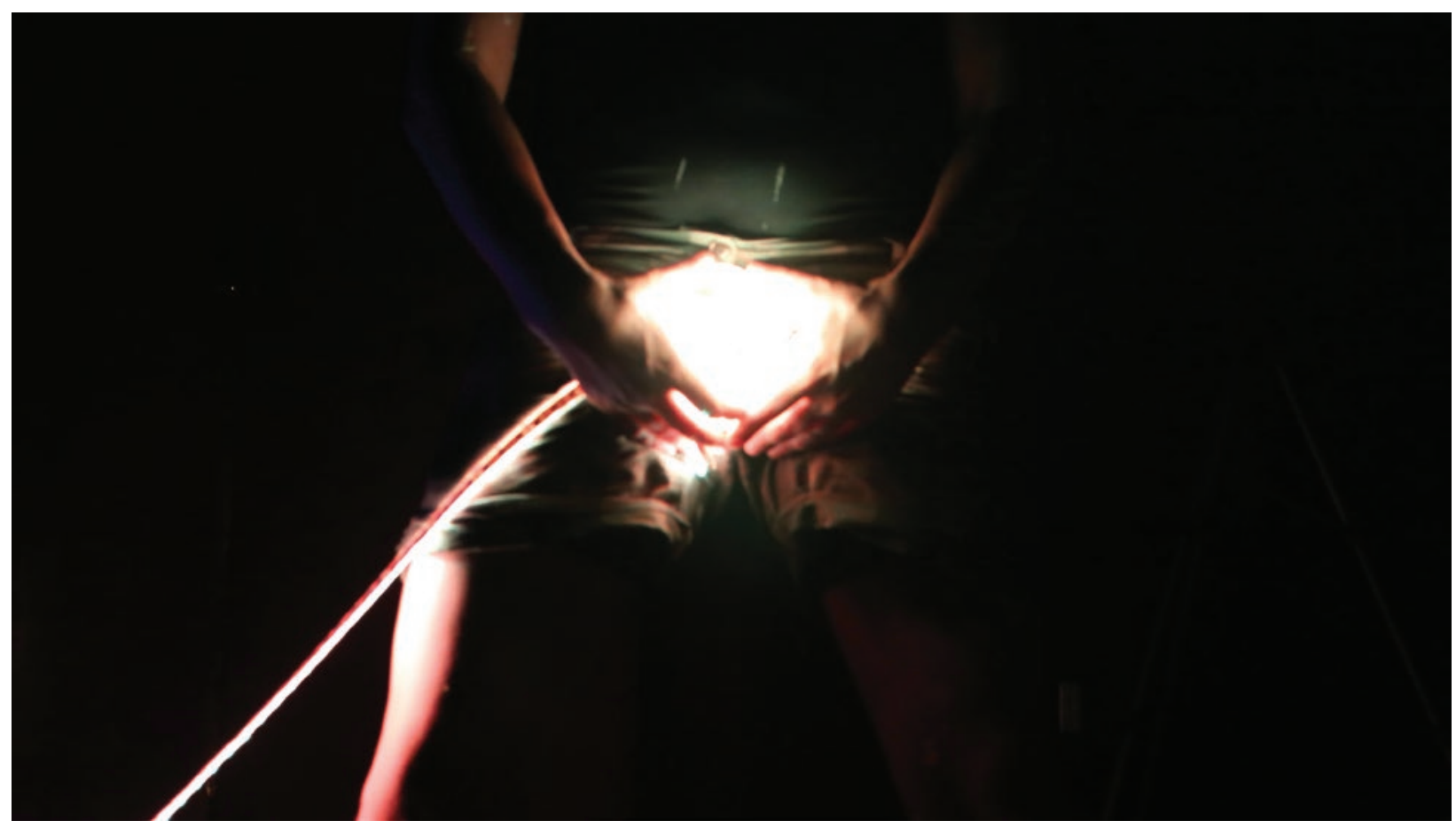

Registro fotográfico da Oficina: A Arte da Performance e a Contrassexualidade da lluminação Cênica Fonte: Marina Mathey

Simões (2013) ao estudar a iluminação no contexto do teatro expressionista alemão destaca, a partir da análise da produção cinematográfica de De manhã à meia noite (1920)7, de Georg Kaiser, observa que a pulsão sexual pode se desenhar a partir da linguagem da luz em cena. Mas como poderia se dar a atuação contrassexual da iluminação cênica no contexto da arte da performance? De acordo com Preciado (2014, p.36):

A ressignificação contrassexual do corpo passa a vigorar com a introdução gradual de determinadas políticas contrassexuais: primeiro, com a universalização das práticas estigmatizadas como abjetas no âmbito do heterocentrismo/cisnormatividade ${ }^{8}$. Segundo, será necessário colocar em movimento equipes de pesquisa contrassexuais high tech, de maneira que se possa encontrar e propor novas formas de sensibilidade e de afeto.

\footnotetext{
7 Título original: Von morgens bis mitternachts, com direção artística de Karlheinz Martin. Disponível em: https://www.youtube.com/watch?v=87JUKRcXsFA, acesso em: 29/10/2019 às 17h44, Porto Seguro / BA, Brasil. Primeira estação cênica analisada por Simões (2013, p.86), corresponde à minutagem do vídeo: início em 1'36" até aproximadamente 7'08".

8 Em atualização do texto de Preciado (2014), acrescentamos a cisnormatividade como padrão hegemônico que remete diretamente à crítica feita pelo autor.
} 


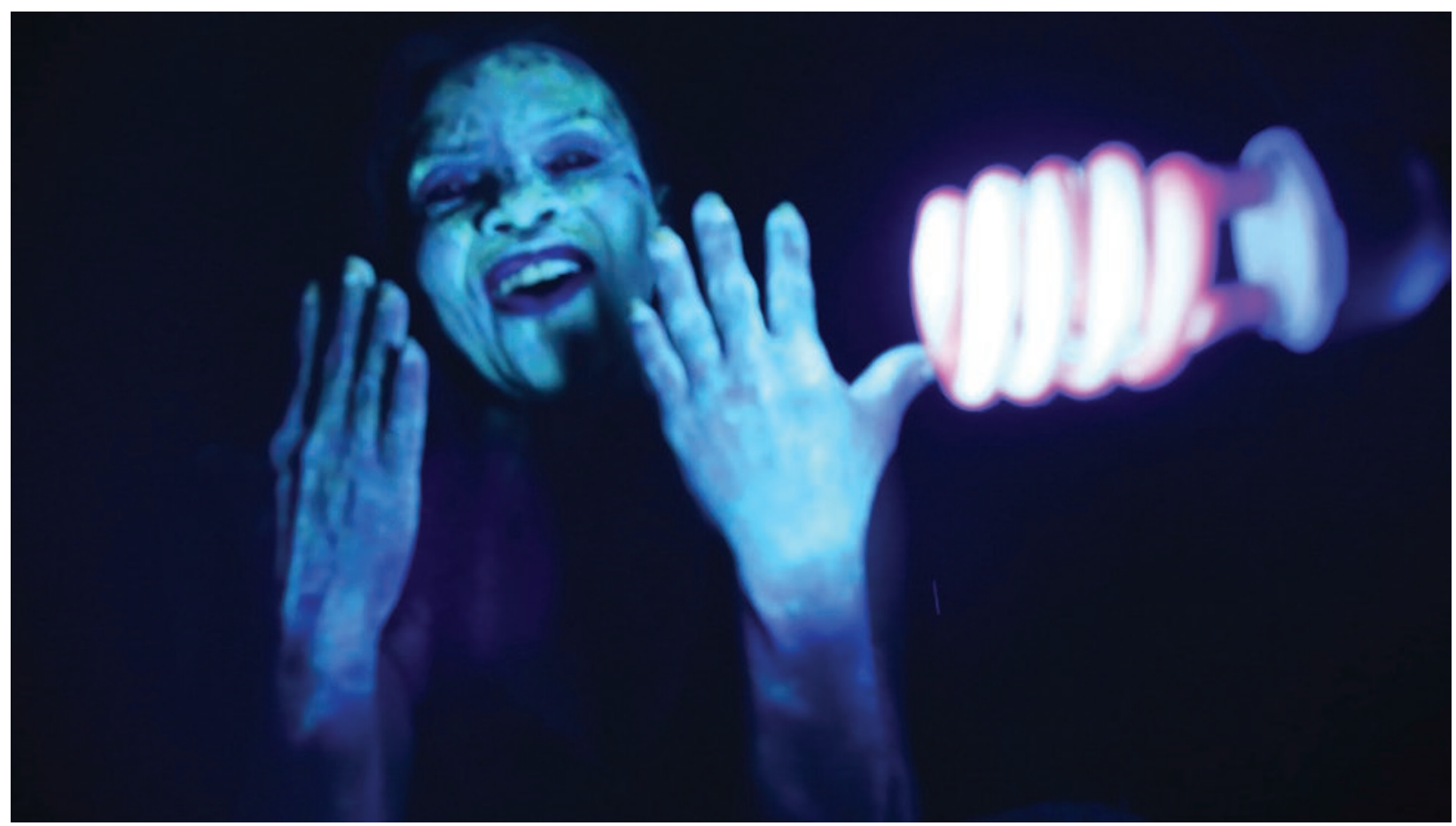

Registro fotográfico da Oficina: A Arte da Performance e a Contrassexualidade da lluminação Cênica Fonte: Marina Mathey

A oficina baseou-se principalmente em 5 momentos. No primeiro momento, 0 grupo foi conduzido a uma vivência corporal com o espaço, vivenciando o estado corporal presente, a respiração, os movimentos e as vocalidades. A relação afetiva de cada pessoa consigo mesma, conduzida com uma sonoridade com uma trilha referenciada na percussividade e interferências eletrônicas (álbum 9/11 da cantora travesti Monna Brutal e álbum Aromanticism de Moses Sumney), estimulando assim diferentes percursos de pesquisa para cada participante.

No segundo momento, foram apresentados os instrumentos de iluminação disponíveis para o trabalho, os quais foram testados no palco com as luzes de serviço desligadas. Tínhamos como materiais: extensões, lâmpada negre, lâmpada de filamento de carbono, lâmpadas de LED, velas, fita de LED com controle multicor, caixinha de som em formato de lâmpada com controle multicor, fita refletiva e patins com rodinhas de luz de LED que acendem com o movimento.

Após o intervalo para o almoço, no terceiro momento, trabalhamos na leitura do exemplo de contrato sexual exposto por Preciado (2014). Na ocasião, refletimos sobre as práticas sexuais hegemônicas em sociedade, as zonas erógenas do corpo, a visualidade das sexualidades em cena e os limites do prazer individual e relacional. Tínhamos como discussão subsequente a iluminação como um dildo, ou seja, perguntamos: de que maneira os aparatos de luz podem produzir prazeres no corpo? Quais as modalidades dos dispositivos de iluminação cênica e como eles poderiam estimular sensações físicas para além da visualidade? Entre o visivo e o térmico, pensamos aí numa conjectura teórica da iluminação cênica pensada a partir das práticas da contrassexualidade. 
[...] durante o primeiro período de estabelecimento da sociedade contrassexual, o dildo e todas suas variações sintáticas - tais como dedos, línguas, vibradores, pepinos, cenouras, braços, pernas, o corpo inteiro etc. -, assim como suas variações semânticas - tais como charutos, pistolas, cacetes, dólares, etc. - serão utilizadas por todos os corpos ou sujeitos falantes no âmbito dos contratos contrassexuais fictícios, reversíveis e consensuais. Parodiar e simular de maneira sistemática os efeitos habitualmente associados ao orgasmo, para assim subverter e transformar uma reação natural construída ideologicamente. No regime heterocentrado/cisnormativo ${ }^{9}$, a limitação e a redução das zonas sexuais são o resultado das definições disciplinares médicas e psicossexuais dos supostos órgãos sexuais, assim como da identificação do pênis e do suposto ponto G como centros orgásticos. (Preciado, 2014, p.37).

No quarto momento desenvolvemos uma atividade textual de escrita em fluxo contínuo. A proposta almejou aproximar a elaboração da prática corporal da luz a partir da produção discursiva, de elementos que vinham a tona espontaneamente a cada participante. $O$ ato de produção textual em torno da relação da luz com o corpo aproximou o grupo da sensação da produção sexual em torno da relação da luz com o corpo. O tempo era comum: 5 minutos. Cada pessoa pôde partir de suas próprias vivências, pulsões e visualidades. No final compartilhamos os textos e o encorajamento do grupo neste momento ficou ainda maior: ouvir a relação de outra pessoa com seu próprio corpo, seus medos, seus orgasmos, suas relações afetivas, inspirou o grupo a seguir para a etapa final da oficina na qual se experimentou a prática da contrassexualidade a partir da iluminação cênica.

Nos modos de um programa performativo, imbuir-se da experiência da textualidade como preparo para a improvisação a partir dos dispositivos de iluminação apresentados, sedimentou o caminho das experimentações. Com indicativos em forma de consigna cênica dadas por Marina Mathey ao longo desta prática final, as/os participantes passavam um tempo buscando a construção, a plasticidade, a visualidade, a temperatura da luz no corpo como maneiras de prazer pessoal e, posteriormente, prazer relacional, na medida em que em estado de jogo, cada pessoa ia espontaneamente encontrando e improvisando com outra/s. Ou não: algumas preferiram ficar o tempo todo sozinhas, em suas próprias descobertas. Novamente o Bukkake apareceu, desta vez tanto enquanto prática individual como relacional da cera/gozo. A luz negre encantou a descoberta da investigação das marcas, traços, cicatrizes e, principalmente, o material químico eventualmente disposto no corpo de cada pessoa: maquiagem, repelente e protetor solar foram os mais comuns a comporem o efeito visual. A fita de LED, velas e as lâmpadas ajudaram a simular órgãos sexuais múltiplos, deslocalizados ou não da região da virilha. Construções no espaço, amarrações de extensão, movimentos contínuos com os patins emissores de luz nas rodinhas (usados enquanto apoio de mãos em ir e vir indicando orgasmo), modos penetrativos e não-penetrativos de prazer, etc.

Por fim avaliamos a oficina. Alguns desconfortos com o próprio corpo foram relatados por alguns/mas participantes. Em outras/os, percebia-se certo desconforto,

\footnotetext{
9 Novamente, em atualização do texto de Preciado (2014), acrescentamos a cisnormatividade como padrão hegemônico que remete diretamente à crítica feita pelo autor.
} 
mas que por ora ainda não ganhava palavras para se descrever. O prazer e as muitas formas de gozo foram destacados por todas as pessoas. Também foram indicadas como força pedagógica da oficina a fluência dos encontros tanto consigo mesmas/ os, quanto com as outras pessoas. A pesquisa de materiais e a refuncionalização da emissão de luz do campo visual para o campo tátil e orgástico foi o aspecto que mais surpreendeu o grupo que foi enfático em indicar a necessidade de continuação dos trabalhos, de possibilidades de vinculação com o ILUMILUTAS e, sobretudo, de aproveitamento dos aportes da oficina para suas criações artísticas respectivas e, ainda, para seus processos subjetivos e afetivos.

\section{Luz e sociedade: iluminação cênica sob a perspectiva de luta de classes}

Nesta seção pretendemos refletir sobre algumas questões preliminares que têm atravessado o percurso do ILUMILUTAS, no que se refere aos aspectos da iluminação cênica e a partir da perspectiva da luta de classes. Primeiramente, a própria reflexão sobre a proveniência, valores, circulação e poder aquisitivo atribuídas aos equipamentos de iluminação cênica remetem-nos às condições sociais de produção da luz.

Um estudo fundamental neste sentido foi realizado por José Sávio Araújo (2011), no qual o autor desenvolve uma análise apurada dos orçamentos de 475 projetos de captação de recursos para a área de Artes Cênicas no quadro do Edital do Programa BNB de Cultura, ano de 2009. Uma primeira constatação é a irregularidade dos gastos em tecnologia cênica (iluminação inclusa), entre as diferentes regiões do país. Ademais, tem-se em síntese que $35 \%$ dos recursos dos 46 projetos a serem aprovados são destinados às tecnologias da cena. E nos perguntamos: quais regiões do país dispõem de circuitos de distribuição de equipamentos de iluminação cênica? E quando se trata, ainda, da fabricação dos mesmos, temos a vulnerabilidade da dependência brasileira às marcas euroestadunidenses.

Pensar a produção da luz a partir da fabricação ou distribuição de equipamentos de iluminação cênica a partir da América Latina nos conduziria a que outros contextos ${ }^{10}$ O que seria uma economia de produção cênica na qual a luz e seus equipamentos são pensados e criados a partir da realidade e das condições efetivas do Nordeste?

A despeito da já mencionada precariedade das condições da UFSB no que se refere ao estado do primeiro ano do ILUMILUTAS, sobre a ausência de equipamentos de iluminação cênica e, apesar de as ordens de compra de tais equipamentos estar em processamento, o projeto estabelece-se diante da produção a partir da realidade que dispõe, sem prejuízo algum da habilidade de reflexão crítica a respeito destas

\footnotetext{
10 De 8 a 12 de julho de 2019, a coordenadora do ILUMILUTAS, Profa. Dodi Leal, esteve em Shanghai, na China, como uma das representantes do Brasil no International Federation for Theatre Research (IFTR) 2019 Meeting, na Shanghai Theatre Academy, com a apresentação do trabalho: BODY IN DIASPORIC VISUALITIES: political and aesthetics dimensions of scenic light. Na ocasião, um dos aspectos nevrálgicos destacado foram as forças geopolíticas da produção da iluminação, tendo em vista as condições urbanas da megalópole Shanghai (que conta com 30 milhões de habitantes aproximadamente), e ornamentos de iluminação em edifícios públicos que tornaram-se referência mundial e têm fortes chances de configurar-se como uma nova potência da criação teatral no mundo, o que implica na corroboração da já ampla indústria de equipamentos eletrônicos misturada com métodos escravagistas de trabalho. Daí pergunta-se: qual o preço pago pelos corpos humanos para que haja luz?
} 
condições $^{11}$. Pelo contrário, entender que se ensina luz a partir dos processos sociais no mais novo curso de Artes da Cena do país e na última universidade federal criada é um marco que se soma e indissocia-se das práticas do grupo.

Em nosso contexto, a tarefa permanente pedagógica em torno dos expedientes da iluminação cênica diz respeito a reinvenção de espaços e não somente a ressignificação de equipamentos de luz. Ainda não temos as salas totalmente adequadas aos trabalhos corporais e de disposição de recursos tecnológicos da cena. Buscamos, entretanto, matizar a ressignificação dos espaços atuais, dentro e fora do campus, buscando as topografias que nos permitem criar e agir em espacialidade. À maneira como Antonio Araújo (2011, p.165) reflete sobre a encenação O Paraíso Perdido e a atividade de criação cênica tendo o edifício de uma igreja como espacialidade não-convencional:

[...] a peça, em sua dimensão ficcional, trataria do exílio e do desterro, enquanto o lugar da representação apontaria para o retorno ou o reencontro com o topos sagrado. A ideia, portanto, era criar uma tensão com o conteúdo abordado, e não uma redundância ou ilustração. Por isso mesmo, para criar esse confronto de significações, o local da representação não poderia constituir-se em "espaço neutro" - apesar de, conceitualmente, não acreditarmos na existência de tal categoria. (Araújo, Antonio 2011, p.165).

Como constante reflexão do grupo, temos as condições sociais da produção cênica da luz como pergunta que instiga a própria inenarrabilidade da iluminação. "Transformar em palavras o que se capta de uma experiência evanescente e fugaz como a da luz, bem como descrever os efeitos que pode causar no/a espectador/a é sempre uma tarefa poética e subjetiva, muito além da evidencia" (Camargo, 2018, p.221). Como nomear os aspectos tecnopolíticos e sócio-críticos da iluminação? Como pôr em palavra uma pedagogia da luz baseada em espaços não-convencionais, seja por opção seja por condição?

Se tomarmos o estudo de Perruchon $(2016, p .45)$ em torno da história da produção da iluminação e sua relação com os contextos sociais, percebemos que luz e poder se associam, tal qual o elemento da escuridão eventualmente mais nos aproximaria da vulnerabilidade, da fraqueza, da pobreza. “Desde o século XVII, a luz é um luxo que é exibido da mesma maneira que os efeitos das máquinas ${ }^{12 " . ~ A i n d a ~ d e ~ a c o r-~}$ do com a autora:

Esses tipos de festas exibem uma despesa luxuosa que a luz representa particularmente, sendo a noite o cenário ideal para valorizá-la. Sua capacidade de destacar o dourado iluminado pelo fogo afeta imediatamente o prazer dos olhos e remete simbolicamente a referência à riqueza e ao poder. (Perruchon, 2016, p.42) ${ }^{13}$.

\footnotetext{
11 O estudante Breno Terra, um dos participantes que esteve no ILUMILUTAS desde sua fundação em outubro de 2018, e com dedicação ativa até o meio do ano de 2019, desenvolveu no segundo semestre deste ano uma instalação com três obras (Lida, transposição e Monumento-Anti), as quais investigam nitidamente a relação da iluminação cênica com a luta de classes. Um dos aspectos mais importantes destes trabalhos é o deslocamento da produção em contextos turísticos ou cotidianos de Porto Seguro, e a interferência no espaço acadêmico do campus, com a inserção de vários elementos que remetem ao trabalho com caixotes, tijolos e cordas. As instalações contam com experiências de provocação das relações sociais de trabalho e a colocação do corpo como dispositivo de experiência da luz (de refletores) que rasga os materiais e a luz (do sol) que faz suar o corpo durante o trabalho.

12 Dès le XVIle, la lumière est un luxe qui s'affiche au même titre que les effets des machines. (Tradução nossa)

${ }^{13}$ Ces types de fêtes exposent une dépense luxueuse que la lumière incarne particulièrement, la nuit étant le cadre idéal pour la mettre en valeur. Sa capacité
} 
Luz é poder. De acordo com Roberto Gill Camargo, somente a não-luz existe, a luz é um acidente ${ }^{14}$. A luz precisa ser gerenciada, precisa ser cortada, editada. A escuridão, por sua vez, tem uma multiplicidade poética talvez ainda maior que a luz, pouco conhecida pelos sentidos humanos, e quiçá impossível de se conhecer em sua completude.

\section{Considerações finais}

Muitas foram as ousadias deste primeiro ano do ILUMILUTAS. Contamos com o apoio imprescindível da coordenação do curso Artes do Corpo em Cena ${ }^{15}$. A entrega e confiança de estudantes da universidade, de vários cursos, foi fundamental para que este projeto iniciasse os trabalhos.

Outras ações novas estão em curso. Dia 24/11/2019 por exemplo, foi oferecida pela Profa. Dodi Leal a Oficina de Dança-Iluminação, no quadro do componente curricular $A$ linguagem da luz nas artes do corpo em cena (oferecida no terceiro quadrimestre do mesmo ano) e também inserida na programação da Semana Nacional de Ciência e Tecnologia do Campus Sosígenes Costa da Universidade Federal do Sul da Bahia de 2019 com o título: "A linguagem da luz nos processos de criação em dança", que contou com a participação de uma média de 40 pessoas. Outra ação coordenada pelo grupo obteve recentemente parecer e aprovação da congregação do Centro de Formação em Artes: a montagem cênica GOTA TRAVA, que empreende o desafio de adaptação da obra de Chico Buarque (Gota d'Água), por sua vez inspirada na de Eurípedes (Medéia) para um olhar delineado pelas transgeneridades contemporâneas na epistemologia da iluminação cênica.

Para o ano de 2020 está prevista a realização do evento de pequeno-médio porte: LUZ A PINO, encontro de performance, corpas e novas tecnologias da cena que pretende anualmente receber coletivos, artistas e pesquisadores/as externos/ as com o intuito de fomentar a discussão teórica e a apresentação de experimentos práticos ligados aos campos da iluminação cênica. É provável que a realização do referido evento se dê em conjunto com o encontro do GT Mulheres da Cena da ABRACE - Associação Brasileira de Pesquisa e Pós-Graduação em Artes Cênicas no Campus Sosígenes Costa da UFSB com realização do ILUMILUTAS.

Em pouco tempo de existência o projeto pedagógico do projeto de pesquisa e extensão ILUMILUTAS/CFA/UFSB não só se articula em um cenário nacional como traz consigo a provocação do redimensionamento da área, para um pensamento de trans pra frente; para olhares pedagógicos da luz que se percebem enquanto processos étnico-raciais, de classe, de gênero, de peso, de sexualidade, etc.

A pergunta que fica, e que deve inspirar novas produções: quais as relações dos marcadores sociais do corpo na ausência de luz, na escuridão, no vazio, na morte,

\footnotetext{
à faire ressortir les dorures illuminées par le feu produit un effet immédiat sur le plaisir des yeux et revêt symboliquement la référence à la richesse et au pouvoir. (Tradução nossa)

14 Em referência à palestra "A luz e não luz" proferida na ocasião da 9a edição do encontro A Luz em Cena, ocorrido na UDESC de 2 a 6 de setembro de 2019.

15 Desde outubro de 2018, o curso Artes do Corpo em Cena é coordenado pelo Prof. Éder Rodrigues da Silva, com vice-coordenação da Profa. Eloisa Domenici.
} 
no fim?

\section{Referências}

ARAÚJO, Antonio. A Gênese da Vertigem - o processo de criação de O Paraíso Perdido. São Paulo: Perspectiva, 2011.

ARAÚJO, José Sávio. O papel da tecnologia cênica e seus desdobramentos para uma economia da produção cultural no Nordeste. In: Moriga - Artes do Espetáculo. Departamento de Artes Cênicas; Centro de Comunicação, Turismo e Arte da UFPB, vol.2, n.1, 2011. João Pessoa: Universidade Federal da Paraíba, 2011.

BONFANTI, Guilherme. A visão de um projeto aberto. In: FERNANDES, Sílvia. Teatro da Vertigem. Rio de Janeiro: Cobogó, 2018.

CABALLERO, Ileana Diéguez. Desmontagem cênica. In: Revista Rascunhos: Caminhos da Pesquisa em Artes Cênicas - Grupo de Estudos e Investigação sobre Processos de Criação e Formação em Artes Cênicas, GEAC; Programa de Pós-graduação em Artes Cênicas da UFU, vol.1, n.1, 2014. Uberlândia: Universidade Federal de Uberlândia, 2014.

CAMARGO, Roberto Gill. Função estética da luz. 1. ed. Sorocaba-SP: TCM Comunicação, 2000.

CAMARGO, Roberto Gill. A escrita e a não escrita da luz. In: Urdimento, v.1, n.31, p.216-224, abril. Florianópolis: Universidade Estadual de Santa Catarina, 2018.

FERNANDES, Sílvia. Teatralidades Contemporâneas. São Paulo: Perspectiva, 2013.

FIGUEIREDO, Laura Maria de. Iluminação cênica: espaço, luz e corpos em foco. In: Urdimento, v.1, n.31, p.152-161, abril. Florianópolis: Universidade Estadual de Santa Catarina, 2018.

JESUS, Jaqueline Gomes. As vozes que escutamos no caminho. In: SMALL, Daniele. ROMAGNOLLI, Luciana. FERNANDES, Sílvia. Revista Cartografias MITsp 2019. São Paulo: Mostra Internacional de Teatro de São Paulo e Escola de Comunicações e Artes da USP, 2019.

KRENAK, Ailton. A Humanidade que Pensamos Ser. In: SMALL, Daniele. ROMAGNOLLI, Luciana. FERNANDES, Sílvia. Revista Cartografias MITsp 2019. São Paulo: Mostra Internacional de Teatro de São Paulo e Escola de Comunicações e Artes da USP, 2019.

LEAL, Dodi. Luzvesti: iluminação cênica, corpomídia e desobediências de gênero. Sal- 
vador: Devires, 2018a.

LEAL, Dodi. Iluminação cênica e desobediências de gênero. In: Revista Aspas, v.8, n.1., p.24-40. São Paulo: Programa de Pós-Graduação em Artes Cênicas da Universidade de São Paulo, 2018b.

LEAL, Dodi. Tochas e coralidades na experiência visual de gênero em cena: dispositivos pedagógicos da luz na recepção teatral. In: Urdimento, v.1, n.34, p.256-265, março/abril. Florianópolis: Universidade Estadual de Santa Catarina, 2019a.

LEAL, Dodi. CORPO EM VISUALIDADES DIASPÓRICAS: dimensões políticas e estéticas da luz cênica. In: Revista Rascunhos: Caminhos da Pesquisa em Artes Cênicas - Grupo de Estudos e Investigação sobre Processos de Criação e Formação em Artes Cênicas, GEAC; Programa de Pós-graduação em Artes Cênicas da UFU, vol.6, n.2, 2019. Uberlândia: Universidade Federal de Uberlândia, 2019b.

PEREZ, Valmir. Luz e Arte: um paralelo entre as ideias de grandes mestres da pintura e o design de iluminação. São Paulo: De Maio Comunicação e Editora, 2012.

PERRUCHON, Véronique. Noir: lumière et théâtralité. Villeneuve d'Ascq, France: Presses Universitaires du Septentrion, 2016.

PRECIADO, Paul. Manifesto Contrassexual: práticas subversivas de identidade sexual. São Paulo, n-1 edições, 2014.

SANTANA, Marcelo Augusto. Haja Luz! Manual de iluminação cênica. Brasília: SENAC, 2016.

SIMÕES, Cibele Forjaz. À luz da linguagem. A iluminação cênica: de instrumento da visibilidade à "Scriptura do visível" \& outras poéticas da luz. Tese (Doutorado em Artes Cênicas). São Paulo: Escola de Comunicações e Artes da Universidade de São Paulo, 2013. 